Corresponding Author: Adhita Mukti Tyasmoro; email: adhitamukti@gmail.com

Dates

Published 28 January 2022

Publishing services provided by Knowledge E

(c) Adhita Mukti Tyasmoro et al. This article is distributed under the terms of the Commons Attribution License, which permits unrestricted use and redistribution provided that the original author and source are credited.

Selection and Peer-review under the responsibility of the ICoPsy Conference Committee.

\section{Correlation Between Political Participation and Well-Being in First-Time Voter Students of the Faculty of Educational Psychology, State University of Malang}

\section{Adhita Mukti Tyasmoro, Tutut Chusniyah, and Huriyah Ar-rohmah}

Faculty of Educational Psychology, State University of Malang

ORCID

Adhita Mukti Tyasmoro; https://orcid.org/0000-0002-0962-9257

Abstract. This research aimed to examine: (1) the level of political participation in students; (2) the level of subjective well-being of students who were first-time voters; and (3) whether there was any correlation between political participation and subjective well-being. This research employed a quantitative approach and a correlation research model. The sample consisted of 90 students of the Faculty of Educational Psychology at the State University of Malang. Data were analyzed using Pearson correlation. The results showed a significant positive correlation between political participation and subjective well-being with a correlation value of 0.438 and a p-value $<0.05$. This indicated that when political participation was high, subjective well-being was also high, and vice versa.

Keywords: political participation, subjective well-being, first-time voter student

\section{Introduction}

Subjective well-being is an individual's subjective evaluation towards life, including concepts such as life satisfaction, pleasant emotions, fulfillment, satisfaction with areas such as marriage and work, low levels of unpleasant emotion[1].State that subjective well-being is an umbrella term for different measures for the level of well-being experienced by individuals according to subjective evaluations of their lives[2]. Subjective well-being is a form of level for which an individual measures their life quality as something expected and feels pleasant emotions [3]. Subjective well-being also refers to something constructive from which includes one's emotional response, the domain of satisfaction, and global assessment of life satisfaction [2]. Subjective well-being indicates life satisfaction, evaluation of essential life domains, their positive emotions, and experiences of few negative emotions. In other words, happiness is the name given to positive thoughts and feelings about one's life [2]. 
Subjective well-being (SWB) itself is very important to be further investigated, where the phenomenon that occurs in the researcher environment and modern life this day, most individuals prioritize career life rather than self-welfare which gives a positive effect on their future lives. This positive effect will cause someone to always get excited, interested in doing activities, and feels happy. Subjective well-being of the Indonesian population is very interesting to investigate considering how subjective well-being is a vast and a complex concept. Researcher sees that various countries in the world have many studies about the correlation between political processes and the quality of individual's life, which includes life satisfaction, happiness, and subjective well-being.

A cross-country study shows that individuals living in regimes that provide greater political freedom can make people happier than those living elsewhere [4]. Research was conducted, and proved the involvement in political activity tends to reduce stress psychologically and can distinguished some mental illness caused by low social status[5]. Furthermore, being involved in political activities is a psychological trait. Using a research from Switzerland conducted, it was found that individuals who have many opportunities to participate in politics directly will be more satisfied with their lives than those who do not [4] [6].

Political psychology is particularly associated with an individual's character and a conducive political system situation. A conducive and ideal political system is emphasized in democracy, which is related to the types of choices of citizens that are many and respected. Not only limited to the abundant information about politics, active political participation, and various political alternatives but also more than that. Participation is a very complex issue in developing countries. Participation is a measure of acceptance of political system built by a country. The progress and development to construct a country are highly dependent on the involvement of its citizen regardless of their gender, both male and female [7].

According to, political participation is citizens who act as individuals intended to influence government's decision-maker. Participation can be individual and collective, organized and spontaneous, steady and sporadic, peaceful or violent, legal or illegal, practical or ineffective [7]. Political participation refers to activities by citizens that are more or less directly aimed to influence government decisions or the actions they take [8]. Provides an understanding regarding political participation. It is a voluntary activity by citizens which they take part in selecting rulers, and directly or indirectly, in the process of forming public policies. Meanwhile, political participation is the activity by ordinary citizens to influence the process of making and implementing public policies, and participating in determining government leaders[9]. 
First-time voters are a subject and also an object in political activities, the activities include the existence of general election activities. First-time voters as an object for political activities, is those who still need guidance in an orientation towards the growth of their potential and abilities in the future, can play a role in the political field [10]. Research, students already have a political culture that is related to civilians, namely their involvement in communities or groups based on their respective interest [11]. The political activities of these students are higher in community service activities rather than practical politics such as voting, campaigning, or political discussions. On the other hand, it was found that when students vote for the first time, they will continue to vote when the opportunity arises because they will feel connected to their community and begin to understand their role as citizens.

Referring to previous matter, the researcher wants to know if political participation and subjective well-being have a significant correlation. The researcher chose students from the Faculty of Educational Psychology, University of Malang, as a subject for this research because every year, all Faculty in University of Malang, held general elections to elect student governors. Therefore, University of Malang is accustomed to participating in politics. Throughout the observations made by researcher, one of the faculties, namely Faculty of Educational Psychology, is a faculty with students who also have different cultures and political behavior. The students of the Faculty of Educational Psychology are accustomed to carrying out political activities such as political discussion by attending an open campaign for student governor, which at the same time conducts campaigns. Throughout the observation that the researcher was conducting, during the election of DMF member, a lot of classmates participate in the open campaigns. However, it is proven that when the student presidential election was held last year, it was found that less than $20 \%$ of the students of the Faculty of Educational Psychology voted.

Researcher used the previous research as a base for this research. Previous research was conducted said that the psychological benefits from political participation is people who participate in political activities will be more satisfied with their lives because it produces feelings of autonomy, competition, and conformity[4]. Participating in making a decision affects one's life and henceforth becomes the basis for the development of human well-being. Subsequent research was conducted by[6], where they conducted a research in Switzerland and found a possibility of correlation between political participation and subjective well-being. 


\section{Literature Review}

\subsection{Political Participation}

The characteristic of a democratic state is how much the state involves the community in planning or implementing general elections. In relation to democracy, political participation affects the legitimacy by the community in the running of a government. In addition, political participation by the community is used as an evaluation and control of the community towards the government. The term participation is taken from English, "participation" which in general can be interpreted as the active participation of citizens in certain activities. In the Political Dictionary, participation is taking part; follow; come along. This term is more popular in interpreting the participation of a person or entity in a job or a big plan. According to Davis in Sastroadmojo political participation is mental and emotional that encourages to contribute to the goals or ideals of the group or is responsible for it.

States that the higher level of political participation indicates that the people follow and understand and involve themselves in state activities. On the other hand, a low level of political participation generally indicates that the people lack appreciation or interest in state issues or activities. The low level of people's political participation is reflected in the attitude of the white group (golput) in elections. Therefore, the level of public political participation in general elections is also very important to be considered, because low or high participation is an important signal and indicator of the course of the democratization process and the embodiment of popular sovereignty.

Beginner voters in the political category are groups that are using their right to vote for the first time. The political orientation of the novice voters is always dynamic and will change according to the existing conditions and the factors that influence it. Beginner voters consisting of students, students or voters with an age range of 17-21 years are indeed a unique segment, often giving rise to surprises and certainly promising in quantity .

\subsection{Subjective Well-being}

Understanding Subjective well-being is a phenomenon that includes cognitive and emotional evaluations of individuals on their lives, such as what lay people call happiness, well-being, full functioning, and life satisfaction [1]. Subjective well-being is defined as an individual's evaluation of his life related to cognitive and emotional components that 
include three main components, namely the number of positive or pleasant affect such as joy, relief. affection, at least experiencing negative or unpleasant affect such as fear, anger, and sadness, as well as personal opinion about life satisfaction[12].

A person is said to have high subjective well-being if he experiences life satisfaction and joy more often, and experiences less unpleasant emotions, such as sadness and anger. On the other hand, a person is said to have low subjective well-being if he or she is dissatisfied with his or her life, experiences little affection and joy, and experiences more negative emotions such as anger or anxiety. Cognitive and affective components of subjective well-being have a high correlation [12]

Adolescent subjective well-being is related to the problems of social and emotional development experienced, namely that the emotional intelligence of early adolescents who are still unstable accompanied by wider early adolescent social interactions, greatly affects the health and subjective well-being of adolescents [13]

\section{Method}

This research is a non-experimental research and a descriptive correlational research type. In this research, the independent variable is political participation. Meanwhile, the dependent variable is subjective well-being.

\subsection{Population and Sample}

The population in this study were students of the Faculty of Educational Psychology, University of Malang, who has voting rights. The number of students of Faculty of Educational Psychology, University of Malang, is around 884 people. The sample in this research was 90 people with the characteristics of active students of the Faculty of Educational Psychology, age 17-21, and registered as permanent voters in the voter list.

\subsection{Research Instrument}

There are three types of instruments in this research, namely (1) the Political Participation Scale to measure the level of political participation of the subject and two scales, namely (2) Satisfaction with Life Scale and (3) SPANE to measure the level of subjective wellbeing of the subject. 


\subsection{Research Procedure}

The study was conducted for 7 days, on April 11-18, 2016. Researcher distributed the political participation scale and subjective well-being scale to 90 students of the Faculty of Educational Psychology, State University of Malang. Researcher also conducted short interviews about subject's political experience.

\subsection{Data Analysis}

Data analysis in this research used descriptive analysis and correlational analysis using Pearson's Product Moment formula. Descriptive statistical analysis is to describe subject's condition in the field about their level of political participation and the level of subject's subjective well-being. Correlational analysis is used to know the correlation between the level of political participation and the level of subjective well-being.

\section{Result}

It is known that from 90 research subject, it was found that students with high levels of political participation were 51 people or $56 \%$, and student with low levels of political participation were 39 people or $44 \%$. It was also found that students with high level of subjective well-being were 53 people or $58 \%$, and students with low levels of subjective well-being were 37 or $42 \%$. With p-value of 0.000 less then alpha of 0.050 , it can be concluded that there is a significant correlation between political participation and subjective well-being. Correlation coefficient value of 0.438 indicates that the closeness of the correlation between political participation and subjective well-being is moderate.

\section{Discussion}

Subjective well-being is described as individual's subjective evaluation of their life, including satisfaction, high positive affect, and low negative affect [1]. There are 2 categories for this research of the students of Faculty of Educational Psychology, State University of Malang, which are high and low. Based on the results of the research described in the previous chapter, it is known that more than half of the students have a high level of subjective well-being, and only a few students have a low level of subjective well-being. 
Categorize subjective well-being into two, namely evaluation (judgement) and affective (emotional) dimension. This dimension of evaluation consists of life satisfaction and affective dimension, includes positive affection and negative affection[1]. Both dimensions certainly influence each other, so that in subjects with low levels of subjective well-being, there is an imbalance between the evaluation dimension and the affective dimension. In the evaluation dimension, not everyone can balance the satisfaction in various areas of life such as family, peers, and the environment. For most individuals balancing family life and peer groups is not as easy as it seems. Not to mention the affective dimension, which includes positive affect and negative affect; in some individuals, it is easier to feel disappointment, anger, sadness, and other. However, as explained in the previous chapter, more students have high levels of subjective wellbeing, apart from how well they balance their evaluation and affective dimensions, but it's also because life in this global era makes it easier for individuals to achieve whatever they want. The pattern of communication is accessible for every individual to make new friends and colleagues. Even in entirely online era, everyone has an opportunity to work and seek additional income from an online business. So now individuals have some kind of 'tools' to make it easier for them to achieve their goals in life. As revealed by Diener, subjective well-being has factors including: (1) gender differences, (2) goals, (3) quality of social connection, (4) personality. The goals here means that people feel happy when they achieve their goals. So, when they can achieve their goals, it will affect emotional and cognitive well-being [1].

The result from this research, not all subjects have high level of political participation. Among all subject, almost half of the subjects have low level of political participation, and most of the subjects have high level of political participation. The research was conducted on students of the Faculty of Educational Psychology was in the age between 18-21. It was declared as first-time voter based on the age. The broader understanding of the meaning of democracy among the people has a significant influence on the nation's political dynamics. One indicator that will get democratic politics going, is the participation of the community in the political field. In our society, there are always unavoidable differences. Likewise, in the political field, everyone has a different mindset and perspective in looking at problems.

First-time voters seem to have enough understanding of the importance in participating politically, along with an understanding the purpose of participating in politics itself. The existence of diverse community indicates each member of the community has various life goals according to their needs, and efforts to meet those needs are 
reflected in the form of activities. Likewise, in political participation, the goals to be achieved are different from one citizen to another.

It seems that first-time voters have started to understand the large number of young generation that Indonesia currently has. They understand that they are capable of determining a better future for Indonesia .

It is also necessary to discuss students, with low political participation, who seem to not fully aware and independent in carrying out their political activities. As research conducted by Hevi Kurnia Hardini, Young Lecturer of FISIP UMM on First-Time Voters, explains that some of the behaviors shown, including; First-Time Voters do not show enthusiasm in facing the election, and the majority are not interested to join political campaigns; First-Time Voters prefer things that are easy and simple to understand. One of the forms is the attitude of choosing the old party because it is considered easy. Too many new things to understand. This is due to a lack of understanding of the importance of political participation; besides that, most first-time voter lack enthusiasm in welcoming the general election, proven by the member of party management, where usually there are no members from the first-time voter group.

However, it should be appreciated because, according to the research described in the previous chapter, the level of political participation in student as first-time voter is relatively high. This is indeed inseparable from the government's role in the socialization of elections. The socialization carried out in various media such as print media, electronic media, and social media give quite good results. In the current global and online era, it is indeed effortless for first-time voter to obtain information related to general election, accessible information gives good effect to the level of first-time voter participation

The hypothesis test results show that there is a significant positive correlation between political participation and subjective well-being, which means that the correlation between the two variables is directly proportional and in line with [4] research, called political participation and quality of life. Based on the research results, there is a significant positive influence between political participation and subjective wellbeing, where the higher the political participation, the higher the level of subjective well-being. The results of this research also support research conducted where they found individuals who have many opportunities to participate directly in politics have greater satisfaction in life than does who does not[6].

As mentioned in the previous chapter, the level of closeness of the correlation between political participation and subjective well-being is moderate, which proves that other factors also influence each variable. The correlation between the two variables 
may be influenced by various factors, such as gender, age, life goals, social relationships, and others.

Participating in politics is also related to individual welfare. Political participation, or in this case, voting behavior, is an expressive and intentional act that a person carries out to show and grow a membership in the community. In addition, why would someone with high level of political participation also has a high level of subjective wellbeing? Because someone who participates politically is likely to be satisfied with voting regardless of the possibility of influencing the outcome of the election, they will feel proud of themselves for participating in the governance process. Political participation also gives citizen a chance to feel ownership of and related to government policies. In conclusion, an individual who have participated politically will feel an immense proud because at least their voice affected government's policy, that will eventually have an effect, which is they will feel more positive emotion, and high level of life satisfaction.

Participating politically can increase happiness and life satisfaction by being creative and deepening a relationship. The citizen's involvement will build a personal relation in hope will be enough contribution. Some studies show that individuals who live in liberal democracies affected their level of happiness and many research also show that happier people will participate in the political process[14]. In addition, individuals who have participated politically by voting will feel more satisfied and prouder because they feel that their voice will more or less affect the quality of democracy in their country. In conclusion, participating in politics is closely related to social environment, meaning that someone who's satisfied with social relations is very likely to have a high level of subjective well-being considering that the environment (both socially and non-socially) is an essential factor that affects the individual's level of subjective well-being.

\section{Conclusion and Recommendations}

Most of the first-time voter level of political participation at the Faculty of Educational Psychology, State University of Malang, is high. Most of the first-time votter level of subjective well being at the Faculty of Educational Psychology, Univeristy of Malang, is high. There is a significant positive correlation between political participation and subjective well-being, meaning that the level of subjective well-being will aso be high if the level of political participation is high. This research is limited, it is recommended that other researchers expand the study of this research further and add more new theories to provide references for the development of psychology. For the next researchers, it 
is hoped that they can also improve the quality of the measuring scale, and that there will be tighter control over other variables.

\section{References}

[1] Diener E. Subjective well-being: The science of happiness and a proposal for a national index. Am Psychology. 2000; 55(1):34-43. Doi.org/10.1037/0003066X.55.1.34

[2] Morrison M, Tay L, Diener E. Subjective well-being and national satisfaction: Findings from a worldwide survey. Psychological Science. 2011;22(2):166-71. DOI: https://doi.org/10.1177\%2F0956797610396224

[3] Diener E. Subjective Well-Being. Psychological Bulletin 95(3) (May 1984): 542-575. DOI:10.1037/0033-2909.95.3.542

[4] Matthew S, Weitz-shapiro R, Winters MS. by. (July 2008): Political participation and quality of life, Working Paper, No.638, Inter-American Development Bank, Research Department, Washington, DC. Available From: urlhttps://www.researchgate.net/publication/23532000_Political_Participation_and _Quality_of_Life

[5] Sanders D, Norris P. The impact of political advertising in the 2001 U.K. general election. Polit Res Q. 2005; 58(4): 525-536. DOI: https://doi.org/10.1177/106591290505800401

[6] Frey BS, Stutzer A. What can economists learn from happiness research? J Econ Lit.June June 2002 ;40(2):402-35. https://www.jstor.org/stable/2698383

[7] Hasbi Wahyudi, Tantio Fernando, Azhari Ahmad, Ayu Khairani, Fatimah, Ivan Muhammad Agung, et al. Peran Kepercayaan politik dan Kepuasan Demokrasi terhadap Partisipasi Politik Mahasiswa. J Psikol UIN Sultan Syarif Kasim Riau. December 2013;9(2):94-9. Doi: http://dx.doi.org/10.24014/jp.v9i2.171

[8] Robert SY. 850 The American Political Science Review. 1979; 79(3):850.Available From: https://www.jstor.org/stable/i333653

[9] Haris M. Potret Partisipasi Politik NU Di Indonesia Dalam Lintasan Sejarah. Jurnal Review Politik. December 2012 ; 2(0): 135-52. Available From: http://jurnalpolitik.uinsby.ac.id/index.php/jrp/article/view/17

[10] Nur Wardhani PS. Partisipasi Politik Pemilih Pemula dalam Pemilihan Umum. Jupiis J Pendidik IImu-IImu Sos. 2018; 10(1): 10-57. DOI: https://doi.org/10.24114/jupiis.v10i1.8407 
[11] Barton H. Political Paticipation of College Students: the Case of Berea College. Paper presented at: Kentucky Political Science Association's Annual Meeting. 2004 February 16, Kentucky.

[12] Utami MS. Keterlibatan dalam Kegiatan dan Kesejahteraan Subjektif Mahasiswa. J Psikol . December 2015;36(1):144-63. Doi: 10.22146/jpsi.7892

[13] Putri DR. Peran Dukungan Sosial dan Kecerdasan Emosi Terhadap Kesejahteraan Subjektifpada Remaja Awal. Indig J IIm Psikologi. May 2016;1(4):12. DOI: https://doi.org/10.23917/indigenous.v1i1.1770

[14] Barker C, Martin B. Participation: The happiness connection. J Public Delib. 2011; 7(0): 1-16. 